\title{
Effectiveness of a Mathematics Instructional Package on Pólya's Steps Including Video Clips to Enhance Problem Solving Abilities of 6th Grade Students in Bhutan
}

\author{
Tenzin Namgyal*1, Kobsook Kongmanus ${ }^{2}$ \\ ${ }^{1}$ Faculty of Education, Naresuan University, Dept. of Educational Technology and Communications, Phitsanulok 65000, Thailand \\ ${ }^{2}$ Faculty of Education, Naresuan University, Dept. of Educational Technology and Communications, Phitsanulok 65000, Thailand \\ *Corresponding author E-mail: tenzinn59@email.nu.ac.th
}

\begin{abstract}
This study investigated three objectives: 1) to determine the effectiveness of a mathematics instructional package on Ploya's steps including video clips to enhance problem solving abilities of 6th grade students in Bhutan, 2) to compare students' mathematics problemsolving abilities before and after implementing the package by using a pretest and posttest, and 3) to examine students' satisfaction level after learning with the mathematics instructional package. In the first semester of 2017, twenty-eight 6th grade students at Khamdang Lower Secondary School in Trashi Yangtse District in Bhutan were selected as the sample by employing the purposive sampling technique. The instruments used in this study were 1) the instructional package (lesson plans on Pólya's steps with video clips), 2) problemsolving ability tests, and 3) questionnaires. The data were statistically analyzed to determine the effectiveness index (E.I), dependent sample t-test, mean and standard deviation. The results revealed that the effectiveness index of the lesson plans of the instructional package was higher than the set criteria of 0.50 . The improvements in problem solving abilities of the students after implementing the instructional package were statistically significant $(\mathrm{p}<0.05)$. The students' satisfaction level after implementation of the instructional package proved to be "very high". In conclusion, the lesson plans on Pólya's steps including video clips were determined to be an effective tool to increase 6th grade students' mathematics problem-solving abilities.
\end{abstract}

Keywords: Pólya's Steps; Problem Solving; Problem Solving Abilities; Mathematics Instructional Package; Videos

\section{Introduction}

The Ministry of Education in Bhutan has a great vision to provide the Bhutanese students with well-equipped education for their lives in the future. Although possessing this great vision, Bhutan originally did not have mathematics textbooks developed particularly for Bhutanese children. Curricula and textbooks from India were therefore adopted for the time being. In the past Bhutanese students faced difficulty learning mathematics since classroom lessons consisted of mostly dictation and rote memorization from the textbook, which did little to encourage students to build problem solving skills by thinking on their own. According to McLean and Hiddleston [1] [2], some of the drawbacks regarding the initial Indian curricula implemented in Bhutan were the unfamiliarity of the Indian contexts described in the textbooks, the incoherent development of concepts and the misalignment of content with the students' ability.

An eventual shift of learning in Bhutan from a conventional style of education to a modern style (i.e. teacher-centered to studentcentered) has opened doors for students to enhance their knowledge, skills, and personal growth. Rapid development in Bhutan and resulting changes in lifestyles have challenged the educational system to adapt and to maintain competitiveness. Policy makers and the curriculum developers in Bhutan are fully aware of the pressing need to prepare present youth for future changes. To this end, in 2003 a team of experts from Canada, along with their Bhutanese counterparts, developed a new
Bhutanese curriculum framework in mathematics for kindergarten (pre-primary) to grade 12, which then began to be implemented only from 2008 [2]. Today public schools in Bhutan teach from the same curriculum framework which is built on a great understanding of constructivist concepts and the development of problem-solving ability [2].

Problem solving according to Skinner [3] is defined as a process of overcoming difficulties when achievement of a goal is blocked. Problem solving acts as an opportunity and launching point for creative thinking in order for real learning to take place. According to Mayer and Hegarty [4], Mathematical problem solving refers to the mental process of finding a solution to a math question for which one does not have a prepared solution ready in advance. Problem solving according to Schoenfeld [5] is interpreted as "working toward achieving a high-priority personal goal". Gagne (1985) said, in order to solve the problem, learner participation is encouraged to construct knowledge in an activity from problem to solution. Problem solving has been called the process of learning "higher order rules". In order to learn rules of a higher level, one should combine the basic rules that brings to the current need for problem solving, as cited in [6]. According to Wilson, Fernandez and Hadaway [7], "Your problem may be modest; but if it challenges your curiosity and brings into play your inventive faculties, and if you solve it by your own means, you may experience the tension and enjoy the triumph of discovery. Such experiences at a susceptible age may create a taste for mental work and leave their imprint on mind and character for a lifetime". Among various interpretations of problem-solving, 
most of the educators, researchers, psychologists, and authors valued teaching and learning of problem-solving as the common core of mathematics which involves critical thinking, imagination, and independent learning Strom, 2013 as cited in [8].

Pólya [9] with his intention to assist "teachers who wish to develop their students' ability to solve problems, and students who are keen on developing their own abilities", originated what he calls the four stages of problem solving, namely: (1) Understand the problem- Students make themselves familiar with the information given and are asked to find out a solution to the problem. (2) Devise a plan- Students look for rules and patterns related to the information given in the problem and create their own procedure to proceed with further steps (solving the problem). (3) Carry out the plan- Students remember and apply the procedures that have been created in the previous step to get the final solution. (4) Look back at the problem- Students analyze and evaluate the procedure used to solve the problem and the solution obtained. Additionally, students decide whether the procedures are effective, whether they can be applied to similar questions, and if other generalizations can be gleaned. Interestingly, Pólya's steps have much in common with the six levels of Bloom's Taxonomy [10], namely: remembering, understanding, applying, analyzing, evaluating and creating to enhance students' abilities to think and reason through a problem. Problem solving is considered essential because it leads the student from the beginnings of their education to higher levels of skill. The natural, instinctive abilities that small children often bring to mathematics, in conjunction with a learning environment where the teacher encourages active problem solving each day, enable young learners to solve problems substantially more complicated than usually considered within their grasp [11] Additionally, the National Council of Teachers of Mathematics [12] mentioned that problem solving is a tool to improve mathematical abilities, beyond simply the goal to learn mathematics. Pólya and Gabor Szego discussed how to make problem solving entertaining and fun [13]. In 2005 Balslev, De Grave, Muijtjens and Scherpbier [14] proved that students' cognitive skills were enriched by employing video as a medium in the classroom.

A video is recognized as one way to present a message through "motion pictures" with the help of electronic media [15]. According to Mayer (2001), a video is a type of multimedia that presents information in two forms: audio and visual, or verbal and pictorial cited in [16]. Sherin [17] described video thus: "Video allows one to enter the world of the classroom without having to be in the position of teaching in-the-moment'. A video presents information to the viewer in an attractive and consistent manner by creating a space for thinking [18]. In these ways, videos can serve the role of a rich and influential medium to boost students' problem solving skills and knowledge [19].

Similar to using video in the learning process, Alshahad [20] said instructional packages also make classroom learning easier and more convenient for both teachers and students. Further, an instructional package provides a platform for the learner to actively participate throughout the instructional time and helps keep the learner continuously engaged [21]. Considering the inherent benefits and significant potential of an instructional package as a vehicle for teaching problem solving techniques, the related ideas from Alshahad [20], and Terathananakul, Kiatkomol and Yampinitch [22] were used in this study in order to investigate the effectiveness of an instructional package on Pólya's steps including video clips and also to evaluate students' improvement in problem solving abilities and the satisfaction level of these $6^{\text {th }}$ grade students in Bhutan after studying with the package.

\subsection{Research objectives}

1) To determine the effectiveness of the mathematics instructiona package on Pólya's steps including video clips.
2) To compare students' mathematical problem-solving abilities before and after implementing the package by using a pre-test and post-test.

3) To examine students' satisfaction level after learning with the mathematics instructional package.

\subsection{Variables of the study}

The variables of the study are:

Independent variable: Effectiveness of the mathematics instructional package on Pólya's steps including video clips.

Dependent variable: Problem solving abilities and satisfaction level of the $6^{\text {th }}$ grade students in Bhutan.

\subsection{Hypothesis}

After implementing the mathematics instructional package, the students' mathematical problem-solving abilities in the posttest will have improved compared to the pretest.

\subsection{METHOD}

According to Ary [23], "the goal of the experimental research is to determine whether a causal relationship exists between two or more variables". Accordingly the present study was based on experimental research to thoroughly fulfill the research objectives.

\subsection{Population and sample}

All $6^{\text {th }}$ grade students of Bhutan were considered to be the population of this study. Students in the same grade generally exhibit the same competency to learn and therefore are assigned to study the same mathematics curriculum nationwide. Students in the same grade also fall within the same age range. Therefore, 28 students from the $6^{\text {th }}$ grade at Khamdang Lower Secondary School in Trashi Yangtse District, Bhutan, were selected by purposive sampling technique to be the sample.

Research instruments

Listed here are the instruments for this research:

Instructional package: This instrument is composed of lesson plans and video clips. The researcher designed 10 lesson plans incorporating Pólya's four steps (i.e. understand the problem, devise the plan, carry out the plan, and look back at the problem) including video clips. The lesson related video clips were downloaded from public online sources. In total, 22 video clips were obtained and used with the lessons to teach 3 chapters (Area, Volume, and Time) in Unit 4: Measurement.

Seven experts (five from Thailand and two from Bhutan) were consulted to review, evaluate, and approve the instructional package. The experts were identified from people who met the maximum number of the following qualifying criteria:

Lecturer/teacher who has background knowledge of the mathematics curriculum.

More than five years of teaching experience in mathematics.

Primary school teacher who has taught more than five years.

Lecturer/Teacher who is very familiar with the Bhutanese curriculum, especially in $6^{\text {th }}$ grade mathematics.

The lesson plans were evaluated for approval by the seven experts using the standard five levels of the Likert Scale, namely: 5 as "Very good", 4 as "Good", 3 as "Average", 2 as "Fair", and 1 as "Poor". The researcher calculated the total mean rating provided by the experts and interpreted it based on Srisa-ard [24] five level scale: 4.50 to 5.00 - very high quality; 3.50 to 4.49 - high quality; 2.50 to 3.49 - average quality; 1.50 to 2.49 - fair quality; and 1.00 to 1.49 - poor quality. In this instructional package, four lesson plans matched "very high quality" and the other six lesson plans matched "high quality".

Test: According to Pólya [9] there are four fundamental steps to enhance students' ability in problem-solving. Those steps are by chance interrelated with the six thinking skills of Bloom's taxon- 
omy as explained here. The first step of Pólya, "Understanding the problem", is related to Bloom's "Understanding". Pólya's second step, "Devise the plan", is related to Bloom's "Creating". Pólya's third step, "Carry out the plan", is related to Bloom's "Applying". Pólya's fourth step, "Look back at the problem", is related to Bloom's "Analyzing and Evaluating". Twenty-five multiple choice questions were designed to compare students' problem-solving abilities before and after learning unit 4: Measurement with the instructional package.

This study employed Kuder-Richardson's formula (KR-20) to find out the reliability coefficient $\left(r_{t}=\frac{n}{n-1}\left[1-\frac{\sum p q}{\sigma_{t}^{2}}\right]\right)$ of the test.

The KR-20 formula established that the test is reliable since the reliability co-efficient $(0.789)$ is greater than 0.70 , the standard value for the reliability of an instrument. The test was subsequently validated by the seven experts using the Index of ItemObjective Congruence $\left(\frac{\sum R}{\mathbb{N}}\right)$. All items of the test showed a mean value greater than 0.67 which indicates validity and acceptability according to Rovinelli and Hambleton [25].

Questionnaire: The researchers designed a 20-item questionnaire in the form of the Likert scale to determine students' satisfaction with using Pólya's steps and the video clips that were implemented in the lesson. The questionnaire was also validated by the seven experts using the IOC (Index of Objective Congruence). All of the statements in the satisfaction questionnaire had a mean IOC value greater than 0.67 , recognizing this questionnaire as valid according to Rovinelli and Hambleton [25].

\subsection{Data collection and Analysis}

Using the ideas of Ary [23], this study followed the "one-group pretest-posttest" design as shown in the table below:

Table I: One-group pretest-posttest design

\begin{tabular}{|l|l|l|}
\hline Pretest & Independent & Posttest \\
\hline $\mathrm{Y}_{1}$ & $\mathrm{X}$ & $\mathrm{Y}_{2}$ \\
\hline
\end{tabular}

The steps involved in this design are (1) administering the pretest $\left(\mathrm{Y}_{1}\right)$; (2) implementing the experimental phase (i.e. teaching with the instructional package on Pólya's steps including video clips) $(\mathrm{X})$; and $(3)$ administering the posttest $\left(\mathrm{Y}_{2}\right)$. After the posttest, the researchers also administered a questionnaire to students to determine their level of satisfaction with the instructional package.

The experimental phase (teaching students with the instructional package) lasted for four weeks in May 2017 (corresponding to the last part of first semester in Bhutan.) To check the effectiveness index (E.I) of the instructional package (lesson plans with video clips) the following formula was used:

$$
\text { E.I }=\frac{\mathbb{Y}_{\mathbf{Z}}-Y_{1}}{\text { Total- } \mathbb{Y}_{1}} \quad(\text { Goodman [26] [27]) }
$$

The data form tests (pretest and posttest) were analyzed with this formula:

$$
t=\frac{\sum D}{\frac{\sqrt{n \sum D^{2}-(\Sigma D)^{2}}}{(n-1)}}
$$

Where, " $t$ " represents the dependent sample t-test, " $D$ " is the difference between pretest and posttest scores, and " $n$ " is the total number of students who took the pretest and posttest, which was all the students in the sample group.

Finally, the satisfaction questionnaire was analyzed using the arithmetic mean $\left(\overline{\mathrm{X}}=\frac{\sum \mathrm{x}}{\mathbb{N}}\right)$ and Standard Deviation

$$
\text { (S. D } \left.=\frac{\sqrt{n \sum x^{2}-\left(\sum x\right)^{2}}}{n(n-1)}\right) \text {. }
$$

\section{Results}

The results of this study were as follows:
To determine the effectiveness of the lesson plans with video clips (instructional package) on enhancing problem solving abilities of the $6^{\text {th }}$ grade students, the effectiveness index (E.I) formula was used. Table 2 below shows the actual values of the variables used to calculate the instructional package's effectiveness index, and the actual calculation itself is shown right below table II.

Table II: Detailed information to calculate the effectiveness index (e.i) of the instructional package

\begin{tabular}{|c|c|c|c|c|}
\hline $\begin{array}{l}\text { Sum of } \\
\text { pretest } \\
\text { scores } \\
\left(Y_{1}\right)\end{array}$ & $\begin{array}{l}\text { Sum of } \\
\text { posttest } \\
\text { scores }\left(Y_{2}\right)\end{array}$ & $\begin{array}{l}\text { Number } \\
\text { of students } \\
\text { (sample) }\end{array}$ & $\begin{array}{c}\text { Full } \\
\text { scores }\end{array}$ & $\begin{array}{l}\text { Total = } \\
\text { (Number of } \\
\text { students } \\
\text { multiplied by } \\
\text { Full scores) }\end{array}$ \\
\hline 416 & 916 & 28 & 50 & 1400 \\
\hline
\end{tabular}

E.I $=\frac{\mathrm{Y}_{2}-\mathrm{Y}_{1}}{\text { Total }-\mathrm{Y}_{1}}=\frac{916-416}{1400-416}=0.51$

The effectiveness index of the lesson plans including video clips (instructional package) to enhance problem solving abilities of the $6^{\text {th }}$ grade students in Bhutan came out to 0.51 thereby meeting the E.I criteria of 0.50 as suggested by [26 27].

To compare students' problem-solving abilities before and after learning with the instructional package, the pretest and the posttest

\begin{tabular}{|c|c|c|c|c|c|c|c|}
\hline Test & $\mathbf{N}$ & $\begin{array}{l}\text { Full } \\
\text { score }\end{array}$ & Mean & SD & $\mathbf{t}$ & df & $\begin{array}{c}\text { Sig. } \\
\text { (2-tailed) }\end{array}$ \\
\hline $\begin{array}{l}\text { Pretest } \\
\text { scores }\end{array}$ & \multirow{2}{*}{$8^{2}$} & \multirow{2}{*}{50} & $86^{14 .}$ & $89^{4.0}$ & \multirow{2}{*}{$\begin{array}{c}- \\
17.724\end{array}$} & \multirow{2}{*}{$7^{2}$} & \multirow{2}{*}{.000} \\
\hline $\begin{array}{l}\text { Posttest } \\
\text { scores }\end{array}$ & & & $71^{32 .}$ & $89^{4.6}$ & & & \\
\hline
\end{tabular}
scores are shown below in table.

Table 3: Dependent sample test for the problem solving abilities test

As seen in Table III. above, the results show that the improvement in problem solving abilities between the pretest and the posttest was statistically significant with a t-value of -17.724 , a df of 27 , and a $\mathrm{p}$ value of 0.000 . Thus these experimental results prove this study's hypothesis, confirming that after implementing the instructional package, the students' mean score in the posttest is higher than in the pretest.

Measurements of the students' level of satisfaction after having learned with the instructional package on Pólya's steps including video clips are presented below in Table IV.

Table IV: Here are the mean $(\overline{\mathrm{x}})$ and standard deviation (s.d) of the student

\begin{tabular}{|c|c|c|c|c|}
\hline Statements & $\mathbf{x}$ & S.D & $\begin{array}{l}\text { Level of } \\
\text { satisfac- } \\
\text { tion }\end{array}$ & Rank \\
\hline $\begin{array}{l}\text { 1. I enjoyed this instructional pack- } \\
\text { age so much that I would like to } \\
\text { know more about these topics. }\end{array}$ & $\begin{array}{l}4.7 \\
9\end{array}$ & $\begin{array}{l}.41 \\
8\end{array}$ & $\begin{array}{l}\text { Very } \\
\text { high }\end{array}$ & 11 \\
\hline $\begin{array}{l}\text { 2. I want to receive this type of } \\
\text { instructional package teaching in } \\
\text { other higher grades. }\end{array}$ & $\begin{array}{l}4.8 \\
6\end{array}$ & .35 & $\begin{array}{l}\text { Very } \\
\text { high }\end{array}$ & 7 \\
\hline $\begin{array}{l}\text { 3. This instructional package was } \\
\text { helpful in understanding the im- } \\
\text { portant concept of the measurement } \\
\text { unit. }\end{array}$ & $\begin{array}{l}4.8 \\
6\end{array}$ & $\begin{array}{l}.44 \\
8\end{array}$ & $\begin{array}{l}\text { Very } \\
\text { high }\end{array}$ & 7 \\
\hline Statements & $\overline{\mathbf{x}}$ & D. $^{\text {S. }}$ & $\begin{array}{l}\text { Level of } \\
\text { satisfac- } \\
\text { tion }\end{array}$ & $\begin{array}{l}\text { Ran } \\
\mathbf{k}\end{array}$ \\
\hline $\begin{array}{l}\text { 4. This instructional package gave } \\
\text { me a feeling of satisfaction after } \\
\text { having learned from those three } \\
\text { chapters (Area, Volume and Time). }\end{array}$ & $\begin{array}{l}4.8 \\
6\end{array}$ & .35 & $\begin{array}{l}\text { Very } \\
\text { high }\end{array}$ & 7 \\
\hline $\begin{array}{l}\text { 5. When the teacher provided a } \\
\text { problem in the class, video clips } \\
\text { helped me to understand it clearly. }\end{array}$ & $\begin{array}{l}4.9 \\
6\end{array}$ & $\begin{array}{l}.18 \\
9^{18}\end{array}$ & $\begin{array}{l}\text { Very } \\
\text { high }\end{array}$ & 2 \\
\hline
\end{tabular}
responses to each satisfaction questionnaire statement (no. of students = 28) 


\begin{tabular}{|c|c|c|c|c|}
\hline $\begin{array}{l}\text { 6. Video clips help me to plan and } \\
\text { solve the question. }\end{array}$ & $\begin{array}{l}4.7 \\
5\end{array}$ & .51 & $\begin{array}{l}\text { Very } \\
\text { high }\end{array}$ & 12 \\
\hline $\begin{array}{l}\text { 7. I could use the ideas gained from } \\
\text { video clips to solve the question } \\
\text { under unit } 4 \text { : Measurement. }\end{array}$ & $\begin{array}{l}4.8 \\
9\end{array}$ & .31 & $\begin{array}{l}\text { Very } \\
\text { high }\end{array}$ & 5 \\
\hline $\begin{array}{l}\text { 8. Comparing my final answer of the } \\
\text { problem with video clips was help- } \\
\text { ful. }\end{array}$ & $\begin{array}{l}4.7 \\
1\end{array}$ & $\begin{array}{l}.60 \\
0\end{array}$ & $\begin{array}{l}\text { Very } \\
\text { high }\end{array}$ & 14 \\
\hline $\begin{array}{l}\text { 9. I enjoyed learning the following } \\
\text { topics; Area, Volume and Time } \\
\text { under measurement unit with video } \\
\text { clips. }\end{array}$ & $\begin{array}{l}4.8 \\
9\end{array}$ & $\begin{array}{l}.31 \\
5\end{array}$ & $\begin{array}{l}\text { Very } \\
\text { high }\end{array}$ & 5 \\
\hline $\begin{array}{l}\text { 10. Solving questions was easier with } \\
\text { Pólya's steps (1. Understand the } \\
\text { problem; } 2 \text {. Devise the plan; } 3 \text {. Carry } \\
\text { Out the plan; and } 4 \text {. Look back the } \\
\text { problem) }\end{array}$ & $\begin{array}{l}4.6 \\
1\end{array}$ & $\begin{array}{l}.62 \\
9\end{array}$ & $\begin{array}{l}\text { Very } \\
\text { high }\end{array}$ & 18 \\
\hline $\begin{array}{l}\text { 11. Learning problem solving was } \\
\text { more activity-based. }\end{array}$ & $\begin{array}{l}4.7 \\
1 \\
\end{array}$ & $\begin{array}{l}.53 \\
5\end{array}$ & $\begin{array}{l}\text { Very } \\
\text { high }\end{array}$ & 14 \\
\hline $\begin{array}{l}\text { 12. Learning problem solving gave } \\
\text { me enough time to think and solve } \\
\text { the problems carefully. }\end{array}$ & $\begin{array}{l}4.7 \\
5\end{array}$ & $\begin{array}{l}.51 \\
8\end{array}$ & $\begin{array}{l}\text { Very } \\
\text { high }\end{array}$ & 12 \\
\hline $\begin{array}{l}\text { 13. After solving a problem through } \\
\text { Pólya's steps, I became more confi- } \\
\text { dent in solving other similar ques- } \\
\text { tions. }\end{array}$ & $\begin{array}{l}4.7 \\
1\end{array}$ & $\begin{array}{l}.46 \\
0\end{array}$ & $\begin{array}{l}\text { Very } \\
\text { high }\end{array}$ & 14 \\
\hline $\begin{array}{l}\text { 14. I used other ways to solve my } \\
\text { questions when problem solving } \\
\text { steps do not seem to work. }\end{array}$ & $\begin{array}{l}4.5 \\
7\end{array}$ & $\begin{array}{l}1.1 \\
03\end{array}$ & $\begin{array}{l}\text { Very } \\
\text { high }\end{array}$ & 19 \\
\hline $\begin{array}{l}\text { 15. I think that Pólya's steps en- } \\
\text { hanced my knowledge in Unit: } 4 \\
\text { Measurement. }\end{array}$ & $\begin{array}{l}4.9 \\
6\end{array}$ & .18 & $\begin{array}{l}\text { Very } \\
\text { high }\end{array}$ & 2 \\
\hline $\begin{array}{l}\text { 16. Solving problems with video } \\
\text { clips about Pólya's steps increased } \\
\text { my self-confidence in mathematics. }\end{array}$ & $\begin{array}{l}4.6 \\
4\end{array}$ & $\begin{array}{l}.62 \\
1\end{array}$ & $\begin{array}{l}\text { Very } \\
\text { high }\end{array}$ & 17 \\
\hline $\begin{array}{l}\text { 17. I think that solving problems with } \\
\text { video clips helps me to make connec- } \\
\text { tions between my previous } \\
\text { knowledge and new information. }\end{array}$ & $\begin{array}{l}4.8 \\
6\end{array}$ & $\begin{array}{l}.35 \\
6\end{array}$ & $\begin{array}{l}\text { Very } \\
\text { high }\end{array}$ & 7 \\
\hline $\begin{array}{l}\text { 18. I think that I explore new things } \\
\text { when I solve the problem through } \\
\text { Pólya's steps. }\end{array}$ & $\begin{array}{l}4.9 \\
6\end{array}$ & $9^{.18}$ & $\begin{array}{l}\text { Very } \\
\text { high }\end{array}$ & 2 \\
\hline Statements & $\overline{\mathbf{x}}$ & S. & $\begin{array}{l}\text { Level of } \\
\text { satisfac- } \\
\text { tion }\end{array}$ & $\begin{array}{l}\text { Ran } \\
\mathbf{k}\end{array}$ \\
\hline $\begin{array}{l}\text { 19. I do NOT feel that the problem } \\
\text { solving lessons are useful. }\end{array}$ & $\begin{array}{l}4.5 \\
7\end{array}$ & $2^{.74}$ & $\begin{array}{c}\text { Very } \\
\text { high }\end{array}$ & 19 \\
\hline $\begin{array}{l}\text { 20. Overall, I am satisfied learning } \\
\text { with video clips and Pólya's steps. }\end{array}$ & $\begin{array}{l}5.0 \\
0\end{array}$ & $\begin{array}{ll}.00 \\
0\end{array}$ & $\begin{array}{l}\text { Very } \\
\text { high }\end{array}$ & 1 \\
\hline Total & $\begin{array}{l}4.8 \\
0\end{array}$ & $\begin{array}{l}0.4 \\
43\end{array}$ & $\begin{array}{l}\text { Very } \\
\text { high }\end{array}$ & \\
\hline
\end{tabular}

The responses to all the statements in this satisfaction questionnaire showed a "very high" level of satisfaction when using the five levels of satisfaction described by [24]. Within the twenty statements, only one statement, number 19, ("I do NOT feel that the problem solving lessons are useful") is phrased as a negative statement. According to Ross [28], negatively worded statement score should be reversed, thus in this research, questionnaire statement 19 'strongly agree' was recorded as ' 1 ' instead of ' 5 ', 'Agree' as '2', 'Neutral' as '3', 'Disagree' as '4', and 'strongly disagree' was recorded as ' 5 '. Therefore, this statement showed a mean of 4.57 and a standard deviation of 0.742 .

All together, the above Table IV calculated to an overall mean of 4.80 and a standard deviation of 0.443 . Thus, the results clearly establish that the students were very satisfied learning with the instructional package about Pólya's steps including video clips to enhance their problem solving abilities.

\section{Discussion}

This research succeeded in determining the effectiveness index (E.I) of the lesson plans on Pólya's steps with video clips at enhancing the mathematics problem solving abilities of $6^{\text {th }}$ grade students at Khamdang Lower Secondary school in Trashi Yangtse, Bhutan.

The effectiveness index (E.I) is a useful assessment tool to measure the effectiveness of any lesson plan or teaching aid. This research revealed that the effectiveness index (E.I) of instructional package is 0.51 which exceeds Goodman [26]'s criteria of effectiveness (equal to 0.5 ). This finding is similar to that in the study of Wattana and Wacharin [27] who studied the production of instructional VCDs for learning science. The effectiveness index in that study was also more than the prescribed criterion 0.5. Additionally, the study carried out by Tiantong and Arreeraad [29] developed learning activities of the data source. Their study also revealed that the effectiveness index was greater than the prescribed criterion of [26].

The study carried out by Chimpoo [30] on problem solving thinking using Backward Design method found out the posttest scores were higher than the pretest scores, with a statistically significant difference of 0.01 , which also means the level of problem solving thinking was high. Similarly, Hudson, Kadan, Lavin and Vasquez [19] studied about "Improving Basic Math Skills Using Technology", and the result of the study revealed that the end score was higher when compared to pre assessment score. In line with these studies, the current study implemented an instructional package to $6^{\text {th }}$ grade students, and the results also showed that the posttest score of the problem solving abilities was higher than the pretest score at the significant level 0.05 as $\mathrm{P}$ value.

To enhance students' problem solving abilities, video clips also assisted teaching and learning in the regular classrooms. LeverDuffy [31] stated, "Video offers some exceptional qualities that make it particularly useful in education. Video can appear to alter both time and space as it captures events. Video captured in real time can be played back in slow motion so that the eyes can see an event that occurred too fast to register through normal vision". According to Nugent [32], videos are used by many teachers to introduce a topic, to review lesson content, to cross check information, or to increase engagement. A video is a widely appropriate tool for many instructional environments, including the whole class, a small group, or an individual. Videos have a particularly dynamic quality that can bring topics to life and make the learners feel transported beyond the walls of the classroom, for example, an object too large to bring into the classroom or some material too small to see with the naked eye can be studied as if they are actually in front of us. Even dangerous experiences can be to observe directly and studied safely [15]. Well established benefits of video usage in the classroom have also encouraged many researchers to carried out their own studies exploring the use of videos. Past researchers like Hudson, Kadan, Lavin and Vasquez [19] [33] used videos in their instruction to check students' improvement in problem-solving skills, abilities, and knowledge in mathematics. Their studies yielded a positive outcome that showed improved abilities in solving the mathematics problems.

Additionally, an improvement in mathematics problem solving abilities in the posttest, the satisfaction level after implementation of an instructional package resulted an overall total mean $(\overline{\mathrm{x}})$ of 4.80 which indicated "very high" according to Srisa-ard [24]'s satisfaction level. This finding is also in line with Terathananakul, Kiatkomol and Yampinitch [22] who studied a computer instructional package for second grade students about careers and technology. Their study resulted in students' satisfaction level being "high" after learning with the computer instructional package. Moreover, another study carried out by Sritaratorn and Sombunsukho [34] on computer instructional package for multimedia also revealed that the students' satisfaction level was high.

\section{Conclusion}

The instructional package on Pólya's steps including video clips was demonstrated to be an effective tool to enhance problem solving abilities of students. According to Anderson [35], problem solving is seen as a useful skill requiring one to analyze, interpret, predict, reason, evaluate and reflect. Similarly, Pólya stated that 
problem solving abilities encourage students to solve the problem efficiently in defined sequential steps. The abilities of problem solving are closely related to the cognitive learning skills of Bloom's Taxonomy (i.e. understand the problem- understanding devise the plan- creating; carryout the plan- remembering and applying, and look back at the problem- analyzing and evaluating). It was found that Pólya's steps have great connection with Bloom's six levels of thinking skill which range from low to higher thinking order. Therefore, the present study determined the effectiveness of the instructional package on the problem-solving abilities of students by comparing their pretest and posttest scores. The students' satisfaction level after having studied with the instructional package was also measured.

The results of the study found that the effectiveness index (E.I) of the instructional package (lesson plans with video clips) on Pólya's steps fulfilled the criterion of effectiveness index $(0.50)$ prescribed by [26 27]. The problem-solving abilities of the students after learning with the instructional package, as reflected in their posttest scores, were better than at the time of the pretest Moreover, the students' level of satisfaction was found to be "very high" according to Srisa-ard [24] levels of satisfaction. Thus the current study's instructional package on Pólya's steps with video clips was determined to be an effective tool to increase $6^{\text {th }}$ grade students' mathematics problem-solving abilities while maintaining a very high level of student satisfaction.

\subsection{Limitations and Suggestions}

Limitations of the current study and suggestions for future research are mentioned here. There were ten lesson plans implemented during the study, but the posttest checked students' learning after all the lessons were taught, not after each lesson. In the future, it might be useful for researchers of a similar study to carry out an assessment after each individual lesson, thereby having access to even greater detailed information.

In the current study it is difficult to be certain if the data collected from the present selected sample accurately reflected the total population of Bhutanese students enrolled in $6^{\text {th }}$ grade in the year 2017. In the future it would be useful to include a larger sample size in similar studies.

This study utilized lesson plans with Pólya's steps and related video clips in the form of an instructional package. All lesson related video clips were obtained from public online sources. When using the video clips in class, in a few instances, students had some difficulty grasping certain content from the video clips because the narrators in some videos clips speak quite quickly, thus from time to time overwhelming the listening skills of some students, occasionally leading to confusion. In this regard, researchers who plan to conduct similar studies in the future, might want to consider producing their own video clips which could then be fine-tuned to the specific listening abilities of the students' age group.

\section{Acknowledgment}

Mr. Tenzin Namgyal would like to convey his sincere gratitude to Naresuan University and the Royal Government of Bhutan for enabling his continued learning and research through the scholarships bestowed upon him. Past researchers are also acknowledged here for their relevant background findings and information that assisted in the current study.

\section{References}

[1] A. C. McLean and P. Hiddleston, Review of the school curriculum of Bhutan with special reference to English and Mathematics, CAPSD, Paro, Bhutan 2003.

[2] P. Dolma, in Investigating Bhutanese mathematics teachers' beliefs and practices in the context of curriculum reform, Queensland University of Technology, 2016, pp. Queensland University of Technology.
[3] C. Skinner, Educational Psychology fourth edition Pretice Hall of India (Pvt.), 1984.

[4] R. E. Mayer and M. Hegarty. "The nature of mathematical thinking" 12, 1996.

[5] A. H. Schoenfeld, Mathematical problem solving, Elsevier, 2014.

[6] T. Bergqvists. Models of the Problem Solving Process-a Discussion Referring to the Processes of Fifth Graders. Proceedings of the Problem Solving in Mathematics Education: Proceeding from the 13th ProMath Conference; Umeå, Sweden, 2011.

[7] J. W. Wilson, M. L. Fernandez and N. Hadaway. "Research ideas for the classroom: High school mathematics" 1993.

[8] C. F. W. Eckenrode, in Teaching Problem Solving In Mathematics: Cognitively Guided Instruction In Kindergarten, 2016.

[9] G. Pólya, How to solve it, Princeton, NJ: Princeton University Press, 1945.

[10] B. S. Bloom. "New York: McKay" 1956.

[11] K. O. Wedekind, Math exchanges: Guiding young mathematicians in small-group meetings, Stenhouse Publishers, 2011.

[12] National Council of Teachers of Mathematics, Principles and standards for school mathematics, NCTM, Reston, VA 2000.

[13] G. Pólya, How to solve it: A new aspect of mathematical method, Princeton university press, 2014.

[14] T. Balslev, W. S. De Grave, A. M. Muijtjens and A. Scherpbier. "Medical education" 39, 112005.

[15] S. E. Smaldino, Instructional technology and media for learning, Pearson, Boston : 2014.

[16] E. Cruse. "URL: http://www. libraryvideo. com/articles/article26. asp" 2011

[17] G. M. Sherin, in New perspectives on the role of video in teacher education, Edited J. Brophy, Elsevier, Oxford,UK 2004, Vol. 10, pp. Elsevier.

[18] C. Sorensen and D. M. Baylen. "The Educational Resources Information Center (ERIC)" 1999.

[19] S. Hudson, S. Kadan, K. Lavin and T. Vasquez, in Improving Basic Math Skills Using Technology, 2010.

[20] H. F. Alshahad. "Journal of KerbalaUniversity" 11, 12006

[21] A. Agudzeamegah, in Developing three-dimensional instructional materials from locally available resources for science education in primary schools, Ghana, Citeseer, 2014, pp. Citeseer.

[22] P. Terathananakul, P. Kiatkomol and S. Yampinitch. "Learning" 2003.

[23] D. Ary, Introduction to research in education, Wadsworth, , Cengage Learning: 2014.

[24] B. Srisa-ard, Introduction to Research Methodology, Suweeriyasart Publishing, Bangkok 2010.

[25] R. J. Rovinelli and R. K. Hambleton. "ERIC Document Reproduction Service (EDRS)" 1976

[26] R. I. Goodman. "Educational Technology" 20, 91980.

[27] P. Wattana and S. Wacharin. "Journal of Education Graduate Studies Research, Khon Kaen University" 2, 22008.

[28] K. N. Ross. "International Institute for Educational Planning/Unesco. Retrieved from www. unesco. org/iiep.[Accessed: 8th may 2014]" 2005.

[29] M. Tiantong and W. Arreeraad. "Journal of Education and Practice" 4, 4 2013.

[30] N. Chimpoo. " The research of Santirat Occupational College: Thailand" 2012.

[31] J. Lever-Duffy, Teaching and learning with technology, Pearson Education, Boston : 2009.

[32] G. C. Nugent. "TechTrends" 49, 42005

[33] H. Y. C. Shyu. "British Journal of Educational Technology" 31, 12000

[34] Developing a computer instructional package for a multimedia program. Proceedings of the 2nd WIETE Annual Conference on Engineering and Technology Education-28 January; 2011.

[35] J. Anderson. "Proceedings of 2009 Australian Curriculum Studies Association National Biennial Conference. Curriculum: A National Conversation" 2009. 